\title{
Development Studies of a New Metronidazole Certified Reference Material
}

\author{
Raquel Nogueira, ${ }^{* a}{ }^{a}$ Werickson F. C. Rocha, ${ }^{a}$ Thaís E. Silva, ${ }^{a}$ Eliane C. P. Rego, ${ }^{a}$ \\ Gabriela F. Moreira, ${ }^{b}$ Wagner Wollinger ${ }^{a}$ and Janaína M. Rodrigues ${ }^{a}$
}

\author{
${ }^{a}$ Divisão de Metrologia Química (Dquim) and ${ }^{b}$ Divisão de Metrologia de Materiais, \\ Instituto Nacional de Metrologia, Qualidade e Tecnologia, (Inmetro), 25250-020 Xerém-RJ, Brazil
}

\begin{abstract}
Este artigo apresenta os resultados dos estudos realizados com o candidato a material de referência certificado (MRC) de metronidazol, primeiro MRC deste fármaco disponibilizado no mercado e segundo MRC de fármacos brasileiro. Os estudos incluem a determinação dos teores de impurezas orgânicas, inorgânicas e voláteis, validação do método analítico de cromatografia líquida de alta eficiência (CLAE), estudos de estabilidade em condições de transporte e estocagem, estudo de homogeneidade, determinação do teor de metronidazol por balanço de massa, confirmação deste valor por calorimetria exploratória diferencial (DSC) e cálculo de incertezas de medição.
\end{abstract}

This paper presents the results of the studies carried out with the candidate certified reference material (CRM) of metronidazole, first CRM of this active pharmaceutical ingredient (API) available on the market and second Brazilian CRM of an API. The investigation includes the determination of organic impurities, inorganic impurities and volatiles, validation of the HPLC-DAD method, stability studies under transport and storage conditions, homogeneity testing, calculation of metronidazole content by mass balance, confirmation of the certified value by differential scanning calorimetry (DSC), and estimation of measurement uncertainties.

Keywords: metronidazole, certified reference materials, active pharmaceutical ingredient (API), analytical quality control, high performance liquid chromatography (HPLC)

\section{Introduction}

Metronidazole (Figure 1) is a 5-nitroimidazole primarily used against protozoal parasites (e.g., Giardia lamblia, Entamoeba histolytica, Trichomonas vaginalis) and anaerobic bacterial infections (e.g., Gardnerella vaginalis). ${ }^{1}$ It is also used in the treatment of gastritis caused by Helicobacter pylori ${ }^{2}$ and for relief of the inflammatory lesions and erythema of rosacea. ${ }^{3}$ Its main pharmaceutical finished products for human use are tablets (oral therapies), as well as gels, creams, or lotions (topical or vaginal therapies). ${ }^{3,4}$

In order to guarantee the quality of pharmaceuticals, the industry and governmental laboratories rely on several tools, including the quality control of raw materials and finished products. For quality control, reference materials (RMs) are highly important, as are the validation of analytical methods and equipment calibration and verification.

Unlike typical RMs, certified reference materials (CRMs) are capable of ensuring metrological traceability

*e-mail: rnogueira@inmetro.gov.br of measurement results to the international system of units (SI), which corresponds to an "unbroken chain of calibrations, each contributing to the measurement uncertainty". ${ }^{5}$ This traceability is a requirement of ISO/IEC 17025:2005; ${ }^{6}$ therefore, accredited laboratories rely on the use of CRMs and other tools to ensure it. Through the use of CRMs, measurement results can be meaningfully compared "over time and place".

The use of CRMs is a common practice in several fields. However, in the pharmaceutical area, the use of reference materials (RM) is much more common; these are typically called reference standards. ${ }^{7}$ It was only in 2008 that the United States Pharmacopeial Convention (USP) began to produce CRMs of active pharmaceutical ingredients (APIs). Until the present year (2011), only four CRMs, namely dextromethorphan hydrobromide, carbamazepine, phenytoin, and theophylline, became available in their catalogue, ${ }^{7,8}$ even though the release of 2500 reference standards had been announced in 2010. ${ }^{9}$ Recently, the National Metrology Institute of Japan (NMIJ) made available the CRM for $17 \beta$-estradiol for clinical chemistry, ${ }^{10,11}$ the National Metrology Institute of China 
(NIM) published the development of a paclitaxel CRM, ${ }^{12}$ and another group developed the anthraquinone CRM in Rhei (Chinese herbal medicine). ${ }^{13}$

In Brazil, national reference standards are produced by the Brazilian Pharmacopeia and the import of USP and European Pharmacopoeia (EP) reference standards is also a common practice. The first Brazilian CRM of an API, the captopril CRM, was made available on the market in 2010 by the National Institute of Metrology, Standardization and Industrial Quality (Inmetro). ${ }^{14,15}$

The requirements for production of CRMs are given by the ISO Guides 34:2009 ${ }^{16}$ and 35:2006 ${ }^{17}$ and include the steps of characterization, short- and long-term stability studies, homogeneity evaluation, and uncertainties estimation. The characterization, in the case of APIs, results in the real analyte concentration in the CRM, which will be reported in a certificate with its measurement uncertainty. The analyte content can be obtained by using methods that directly give this value or else by indirect approaches, like the mass balance calculation, which is based on a difference $(100 \%-\Sigma$ impurities $) .{ }^{18}$ Besides giving important information about the analyte impurity profile, ${ }^{19}$ the mass balance results in smaller uncertainties of the property value, even if larger uncertainties are obtained for the individual impurities. ${ }^{18,20}$ This was the approach used here for the certification of the metronidazole CRM and the certified property value was cross-checked by differential scanning calorimetry (DSC).

This paper details all of the studies performed with the Inmetro first batch of the candidate CRM of metronidazole.

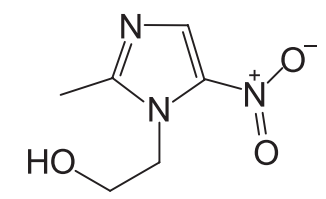

Figure 1. Metronidazole chemical structure.

\section{Experimental}

Instruments and apparatus

A high performance liquid chromatography (HPLC) system (Shimadzu, Kyoto, Japan), consisting of a LC-20AT quaternary pump, a DGU-20A 3 /DGU-20A on-line degasser, a SIL-20A/20AC auto-sampler, a SPD-20A photodiode array detector, and a CBM-20A/20A interface, was used for the determination of related substances. Lab Solution software was used for data processing. The experimental conditions were: HPLC reversed-phase column $\mathrm{C} 18,25 \mathrm{~cm} \times 4.6 \mathrm{~mm}$ i.d., $5 \mu \mathrm{m}$, Nucleosil (Macherey Nagel, Dueren, Germany), pre- column C18, 4.6 mm i.d., 5 um (Varian, Inc.; Palo Alto, USA), mobile phase $1.36 \mathrm{~g} \mathrm{~L}^{-1}$ potassium dihydrogen phosphate-methanol (70:30, v/v), flow-rate $1.0 \mathrm{~mL} \mathrm{~min}^{-1}$, UV detection at $315 \mathrm{~nm}$.

The water content was determined using a Karl Fischer coulometer (831 model, Metrohm AG, Bleiche West, Switzerland) equipped with a generator electrode without a diaphragm, a current generator electrode (400 mA) and a platinum indicator electrode $(10 \mu \mathrm{A})$, connected to an oven sample processor (774 model, Metrohm), a stirrer (728 model, Metrohm) and a controller (774 SC model, Metrohm). The experimental conditions were: oven temperature, $105^{\circ} \mathrm{C}$; end point voltage, $50 \mathrm{mV}$; extraction

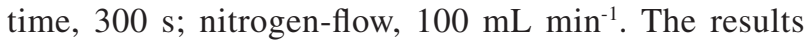
were processed with Tiamo 1.2 software, 2006 version (Metrohm).

The differential scanning calorimetry measurements were performed using a DSC Q2000 (TA Instruments, New Castle, USA) and processed with TA Universal Analysis 2000 software. The DSC cell was calibrated with a sapphire disk (TA Instruments) (baseline calibration) and indium SRM 2272 from NIST (enthalpy and temperature calibration). The purity determination was performed according to method A of ASTM Standard E 928-08 ${ }^{21}$ and consisted of heating 1-3 mg samples, hermetically sealed in an aluminum pan, at $0.5^{\circ} \mathrm{C} \mathrm{min}^{-1}$ under dynamic nitrogen gas-flow $\left(50 \mathrm{~mL} \mathrm{~min}^{-1}\right)$.

All sample solutions were prepared gravimetrically using an analytical balance (Shimadzu), model AUW 220D, with resolution of $0.01 \mathrm{mg}$.

\section{Reagents and chemicals}

The studies were carried out using the Inmetro first batch of the metronidazole candidate CRM. After satisfactory results in the tests according to the Brazilian Pharmacopeia IV monograph, ${ }^{22}$ amber glass flasks were filled with $525 \mathrm{mg}$ metronidazole (nominal mass: $500 \mathrm{mg}$, excess: $5 \%$ ) under controlled temperature and humidity conditions, closed with rubber stoppers and aluminum seals and identified with the CRM name and a sequential number. All of the tests were performed with the material packed as sent to the customer. The CRM was dried at $105^{\circ} \mathrm{C}$ for $2 \mathrm{~h}$ prior to use in the HPLC related substances test, while it was used without prior drying for the homogeneity and stability studies.

A USP reference standard of metronidazole (batch J11272, $100.0 \%$ ) and EP reference standard of metronidazole impurity A (batch $2.1,100.0 \%$ ) were also analyzed by HPLC for comparison. The metronidazole USP reference standard was dried at $105^{\circ} \mathrm{C}$ for $2 \mathrm{~h}$ prior to 
use. The reagents were HPLC grade methanol (Tedia, Rio de Janeiro, Brazil), potassium dihydrogen phosphate p.a. (Sigma Aldrich, St. Louis, USA), hydrochloric acid p.a. (Merck, São Paulo, Brazil), sodium hydroxide p.a. (Merck), hydrogen peroxide $30 \%$ p.a. (Merck) and water type I (Millipore, Bedford, USA). For the Karl Fischer coulometric titration, a Coulomat AG solution (Riedel-de Haen, Seelze, Germany) was used.

\section{Candidate CRM characterization}

The content of API in the Inmetro first batch of metronidazole candidate CRM was determined using the mass balance approach according to equation 1 (Table 1). In order to use this equation, it is essential to determine with accuracy the content of organic, inorganic, and volatile impurities.

The organic impurities were determined by HPLC-DAD based on the related substances test in the European Pharmacopoeia V monograph. ${ }^{23}$ Solutions containing 500,5 , and $0.5 \mu \mathrm{g} \mathrm{g}^{-1}$ of metronidazole (previously dried) in mobile phase were prepared in triplicate from each candidate CRM flask, and each solution was injected three times into the HPLC system. This test was repeated on three different days. The content of each organic impurity in the CRM samples was determined by peak area ratio according to equation 2 (Table 1 ). The inorganic impurities were determined by residue on ignition (sulfated ash) and the volatiles by loss on drying $\left(105^{\circ} \mathrm{C}\right.$ per $2 \mathrm{~h}$ ) according to the Brazilian Pharmacopeia IV. ${ }^{22}$ The loss on drying results were compared to the water content determined by Karl Fischer coulometric titration (oven method).

\section{HPLC-DAD method validation}

The method specificity was evaluated by analysis of the diluent (mobile phase), metronidazole impurity A EP reference standard ( 5 and $0.5 \mu \mathrm{g} \mathrm{g}^{-1}$ solutions), metronidazole USP reference standard $\left(500,5\right.$ and $\left.0.5 \mu \mathrm{g} \mathrm{g}^{-1}\right)$, metronidazole CRM samples (500, 5 and $0.5 \mu \mathrm{g} \mathrm{g}^{-1}$ ), and mixtures of metronidazole CRM and metronidazole impurity A EP reference standard (500 and $5 \mu \mathrm{g} \mathrm{g}^{-1}$, respectively). Additionally, samples of metronidazole CRM were exposed to the following stress conditions: $170{ }^{\circ} \mathrm{C}$ for $1 \mathrm{~h}, \mathrm{UV}$ at $254 \mathrm{~nm}$ for $24 \mathrm{~h} ; 1 \mathrm{~mol} \mathrm{~L}^{-1} \mathrm{HCl}, 1 \mathrm{~mol} \mathrm{~L}-1 \mathrm{NaOH}$, or $3 \%$ $\mathrm{H}_{2} \mathrm{O}_{2}$ for $1 \mathrm{~h}$. After treatment, the samples were neutralized (in case of acidic or basic conditions) and diluted with mobile phase to 500 and $5 \mu \mathrm{g} \mathrm{g}^{-1}$.

In order to evaluate the metronidazole stability in the diluent (mobile phase), 500 and $5 \mu \mathrm{g} \mathrm{g}^{-1}$ solutions of metronidazole CRM were transferred to HPLC vials, kept
Table 1. Equations used in the certification studies of the metronidazole candidate CRM

\begin{tabular}{|c|c|}
\hline \multicolumn{2}{|l|}{ Equations* } \\
\hline $\begin{array}{c}\text { Metronidazole }(\%)=100 \%-\Sigma \text { organic imp. }(\%)- \\
\sum \text { inorganic imp. }(\%)-\Sigma \text { volatiles }(\%)\end{array}$ & (1) \\
\hline$[$ org $]=\frac{\mathrm{A}_{\text {imp }} \times 100}{\left(\mathrm{~A}_{\text {metr dil }} \mathrm{DF}\right)+\Sigma \mathrm{A}_{\mathrm{imp}}}$ & (2) \\
\hline$u_{\text {org }}=\sqrt{\sum_{i=1}^{N}\left(\partial_{o r g} / \partial_{x i}\right)^{2} u_{x i}^{2}}$ & (3) \\
\hline $\mathrm{u}_{\mathrm{c}}=\mathrm{x} \sqrt{(\mathrm{SD} / \sqrt{\mathrm{n}} \mathrm{x})^{2}+(\mathrm{U} / \mathrm{k} \mathrm{m})^{2}}$ & (4) \\
\hline $\mathrm{u}_{\mathrm{bb}}=\sqrt{\left(\mathrm{MS}_{\text {between }}-\mathrm{MS}_{\mathrm{within}}\right) / \mathrm{n}}$ & (5) \\
\hline $\mathrm{u}_{\mathrm{stab}}=\mathrm{s}_{(\mathrm{b} 1)} \mathrm{t}$ & (6) \\
\hline $\mathrm{u}_{\mathrm{CRM}}=\sqrt{\mathrm{u}_{\mathrm{org}}{ }^{2}+\mathrm{u}_{\mathrm{inorg}}{ }^{2}+\mathrm{u}_{\mathrm{vol}}{ }^{2}+\mathrm{u}_{\mathrm{bb}}{ }^{2}+\mathrm{u}_{\mathrm{lts}}{ }^{2}}$ & (7) \\
\hline $\mathrm{U}=\mathrm{u}_{\mathrm{CRM}} \mathrm{k}$ & (8) \\
\hline $\mathrm{T}_{\mathrm{S}}=\mathrm{T}_{0}-\frac{\mathrm{R}_{0}^{2} \chi}{\Delta \mathrm{H}} \frac{1}{\mathrm{~F}}$ & (9) \\
\hline 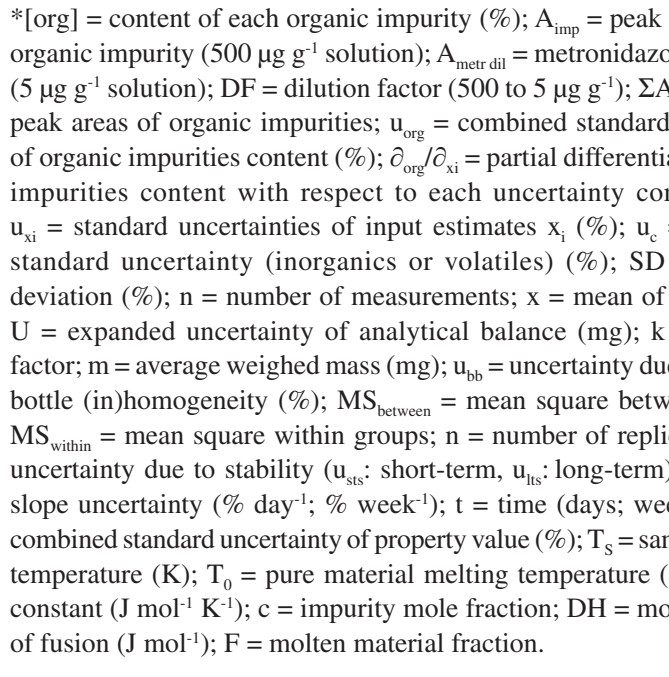 & $\begin{array}{l}\text { of each } \\
\text { eak area } \\
=\text { sum of } \\
\text { ertainty } \\
\text { organic } \\
\text { nent } \mathrm{x}_{\mathrm{i}} \text {; } \\
\text { mbined } \\
\text { tandard } \\
\text { lts }(\%) \text {; } \\
\text { overage } \\
\text { petween } \\
\text { groups; } \\
\text {; } \mathrm{u}_{\text {stab }}= \\
\text { ); } \mathrm{s}_{\text {(bl) }}= \\
\mathrm{u}_{\mathrm{CRM}}= \\
\text { melting } \\
\mathrm{R}=\text { gas } \\
\text { nthalpy }\end{array}$ \\
\hline
\end{tabular}

at $15{ }^{\circ} \mathrm{C}$ in the auto-sampler, and injected three times into the HPLC at 0, 5.7, 11.8, 17.8, 32.7, 53.6, and $80.5 \mathrm{~h}$.

For linearity evaluation, 16 solutions of metronidazole USP reference standard or metronidazole impurity A EP reference standard in the concentration range between 500 and $0.01 \mu \mathrm{g} \mathrm{g}^{-1}$ were analyzed. The limit of quantitation (LOQ) and the limit of detection (LOD) were estimated from the linearity results in the range between 1.0 and $0.010 \mu \mathrm{g} \mathrm{g}^{-1}$, which was appropriate for observation of responses (peak heights) equivalent to 10 or 3 times the noise (LOQ and LOD, respectively), as required by the signal-to-noise $(\mathrm{S} / \mathrm{N})$ ratio method. ${ }^{24}$ Only results above LOQ were considered in the regression analysis for linearity evaluation. 
The repeatability was evaluated by six repeated injections of metronidazole CRM (500, 5 and $\left.0.5 \mu \mathrm{g} \mathrm{g}^{-1}\right)$. This test was repeated on a different day by a different analyst to verify the intermediate precision. The recovery tests for accuracy (and also specificity) evaluation were performed using solutions of metronidazole impurity A EP reference standard $\left(2.5,5.0\right.$ and $\left.10.0 \mu \mathrm{g} \mathrm{g}^{-1}\right)$, with or without addition of $500 \mu \mathrm{g} \mathrm{g}^{-1}$ of metronidazole CRM. This CRM was used as a matrix and was individually analyzed to determine the metronidazole impurity A content, which was subtracted before recovery calculation.

The method robustness evaluation was planned according to Youden and Steiner, as described by Bedregal et al., ${ }^{25}$ and consisted of eight HPLC analyses of metronidazole CRM (500 and $5 \mu \mathrm{g} \mathrm{g}^{-1}$ ) with variations in mobile phase flow-rate (A: $1.05 \mathrm{~mL} \mathrm{~min}^{-1}$, a: $0.9 \mathrm{~mL} \mathrm{~min}^{-1}$ ), detection wavelength (B: $320 \mathrm{~nm}$, b: $310 \mathrm{~nm}$ ), $\mathrm{KH}_{2} \mathrm{PO}_{4}$ concentration (C: $1.46 \mathrm{~g} \mathrm{~L}^{-1}$, c: $\left.1.26 \mathrm{~g} \mathrm{~L}^{-1}\right)$, and methanol concentration: (D: $33 \%$, d: $27 \%$ ).

Homogeneity testing, short- and long-term stability studies

The between-bottle variation was evaluated using 13 candidate CRM flasks selected at random and analyzed in triplicate. The HPLC analysis was done as previously described, the content of organic impurities was calculated by equation 2 (Table 1 ) and the metronidazole content was determined by mass balance according to equation 1 (Table 1).

For the short-term stability study, 10 CRM flasks selected at random were exposed simultaneously to the temperature of $50{ }^{\circ} \mathrm{C}$. On pre-determined days $(1,4,8$,
$10,15,29,31,52,64$, and 66), one flask was taken out of the oven and individually analyzed (classical design). Solutions containing 500, 5, and $0.5 \mu \mathrm{g} \mathrm{g^{-1 }}$ were prepared in triplicate from each CRM flask, and each solution was injected three times into the HPLC system. Three other CRM flasks, kept at the reference temperature of $25^{\circ} \mathrm{C}$ and analyzed in the same way, were used as controls $(\mathrm{t}=0)$. The metronidazole content was calculated by mass balance according to equation 1 (Table 1).

For the long-term stability study, CRM samples were kept at the recommended storage conditions $\left(25^{\circ} \mathrm{C}\right)$ and analyzed four times throughout the year of certification studies, namely in the $1^{\text {st }}, 25^{\text {th }}, 34^{\text {th }}$, and $42^{\text {th }}$ weeks. At each time, three flasks were analyzed in triplicate. After conclusion of this study, a monitoring program of the CRM samples was started.

\section{Estimation of measurement uncertainties}

The uncertainty estimation was performed according to the Eurachem/Citac Guide ${ }^{26}$ and the relevant uncertainty sources can be seen in the cause and effect diagram (Figure 2). Based on equation 1 (Table 1), the uncertainties due to the determination of organic, inorganic, and volatile impurities were included. The combined standard uncertainty of the organic impurities content $\left(\mathrm{u}_{\mathrm{org}}\right)$ was calculated by equation 3 (Table 1). The considered uncertainty sources were essentially the variables of equation 2 (Table 1), but possible differences in specific absorptivities of metronidazole and its impurities were also taken into account. The combined standard uncertainties $\left(u_{c}\right)$ of the contents of inorganic or volatile impurities ( $\mathrm{u}_{\text {inorg }}$ and $\mathrm{u}_{\mathrm{vol}}$, respectively) were individually calculated by equation 4 (Table 1 ).

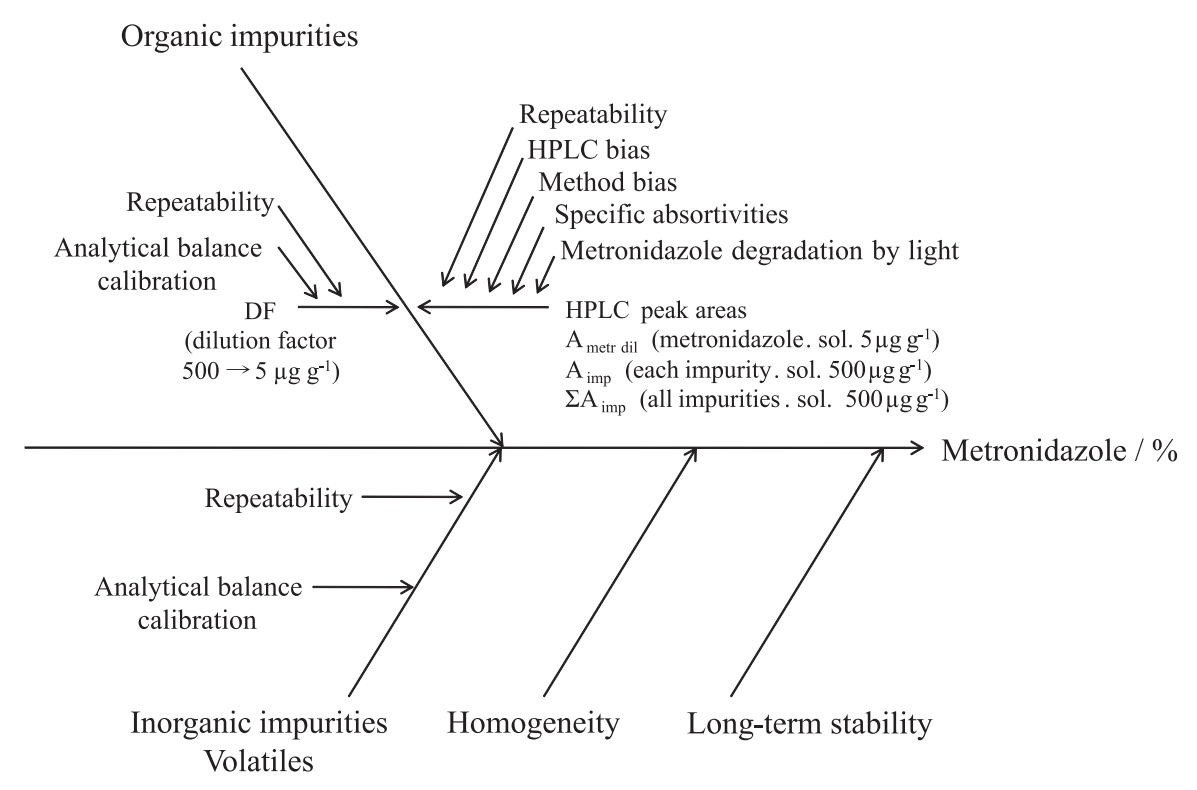

Figure 2. Cause and effect diagram with uncertainty sources for metronidazole candidate CRM. 
Additionally, the uncertainty due to between-bottle (in) homogeneity $\left(\mathrm{u}_{\mathrm{bb}}\right)$ was calculated by equation 5 (Table 1 ), while the short- and long-term stability uncertainties $\left(\mathrm{u}_{\mathrm{sts}}\right.$ and $\mathrm{u}_{\mathrm{ts}}$, respectively) were estimated using equation 6 (Table 1), according to the ISO Guide 35:2006. ${ }^{17}$ As will be explained later, $\mathrm{u}_{\mathrm{sts}}$ was not taken into account in the calculation of the combined standard uncertainty of the CRM property value $\left(\mathrm{u}_{\mathrm{CRM}}\right)$, which was carried out using equation 7 (Table 1) according to the law of propagation of uncertainties ${ }^{26}$ and verified by the Kragten method, which is also derived from this law, but is based on the separation of the contribution of different error sources. ${ }^{26,27}$ Finally, the CRM expanded uncertainty (U) ${ }^{26}$ was calculated by equation 8 (Table 1).

\section{Results and Discussion}

The certification steps were: (i) HPLC-DAD method validation; (ii) CRM characterization (determination of contents of organic, inorganic, and volatile impurities); (iii) homogeneity testing; (iv) short-term stability studies; (v) long-term stability studies; and (vi) property value assignment by mass balance. Whenever applicable, the uncertainties were estimated.

\section{HPLC-DAD method validation}

The determination of related substances (organic impurities from synthesis or degradation products) of metronidazole was performed by HPLC-DAD according to the European Pharmacopoeia V monograph. ${ }^{23}$ The Brazilian Pharmacopeia $\mathrm{IV}^{22}$ and the United States Pharmacopeia $32^{28}$ recommend the use of thin layer chromatography for evaluation of metronidazole related substances, which was not appropriate for certification purposes.

The validation results of the HPLC-DAD method are summarized in Table 2, while Figures 3-5 show chromatograms of metronidazole CRM, metronidazole USP reference standard, and metronidazole impurity A EP reference standard, respectively. In the specificity tests, from all tested stress conditions $\left(170{ }^{\circ} \mathrm{C}\right.$ for $1 \mathrm{~h}$; UV $254 \mathrm{~nm}$ for $24 \mathrm{~h} ; 1 \mathrm{~mol} \mathrm{~L}^{-1} \mathrm{NaOH}, 1 \mathrm{~mol} \mathrm{~L}^{-1} \mathrm{HCl}$, or $3 \% \mathrm{H}_{2} \mathrm{O}_{2}$ for $1 \mathrm{~h}$ ), only the basic $\mathrm{pH}$ condition resulted in significant changes in the metronidazole content (reduced from $99.60 \%$ to $96.03 \%$ ) and in the impurity profile (new impurity peaks, increase in peak areas of some impurities). However, the metronidazole peak was still well resolved from the impurity peaks and its peak purity index was preserved (0.9996), demonstrating the method specificity. Even though the metronidazole instability upon exposure to light has been reported, ${ }^{22}$ this effect was not observed.
The linearity was evaluated in the range between LOQ and $500 \mu \mathrm{g} \mathrm{g}^{-1}$, and also between LOQ and $10 \mu \mathrm{g} \mathrm{g}^{-1}$, which is the most probable concentration range for impurities, considering the limits of $0.5 \mu \mathrm{g} \mathrm{g}^{-1}$ for each impurity and $1.0 \mu \mathrm{g} \mathrm{g}^{-1}$ for total impurities $(0.1 \%$ and $0.2 \%$, respectively, of $\left.500 \mu \mathrm{g} \mathrm{g}^{-1}\right) .{ }^{23}$ The regression analysis resulted in squared correlation coefficients $\left(\mathrm{r}^{2}\right)$ of at least 0.9996 for metronidazole and 1.0000 for metronidazole impurity A. Therefore, the method linearity ${ }^{29}$ was demonstrated.

The repeatability results indicated a smaller standard deviation of normalized peak areas for the $5 \mu \mathrm{g} \mathrm{g}^{-1}$ solutions compared to the $0.5 \mu \mathrm{g} \mathrm{g}^{-1}$ solutions. Therefore, the variables of equation 2 (Table 1) related to the diluted solution were associated with the $5 \mu \mathrm{g} \mathrm{g}^{-1}$ concentration.

For robustness evaluation, eight HPLC analyses were performed with variations in mobile phase flow-rate (variables $\mathrm{A} / \mathrm{a}$ ), detection wavelength (variables $\mathrm{B} / \mathrm{b}$ ), $\mathrm{KH}_{2} \mathrm{PO}_{4}$ concentration (variables $\mathrm{C} / \mathrm{c}$ ), and methanol concentration: (variables D/d). From the results of the eight experiments (s: 99.5986, t: 99.6026, u: 99.5878, v: $99.5996, w: 99.5925, x: 99.5954, y: 99.5945$, and z: $99.5974 \%$ ), the values of the variables were determined to be $\mathrm{A}=99.5972, \mathrm{a}=99.5950, \mathrm{~B}=99.5973, \mathrm{~b}=99.5948$, $\mathrm{C}=99.5934, \mathrm{c}=99.5978, \mathrm{D}=99.5983$, and $\mathrm{d}=99.5938 \%$. According to Bedegral et al. ${ }^{25}$ if the differences (absolute values) between the results for the upper case variable (nominal condition) and their corresponding lower case variable (departure condition), for instance $|\mathrm{A}-\mathrm{a}|$, are not larger than $s \sqrt{ } 2$, where $s$ is the standard deviation of results, the variable has an insignificant effect and the method is not sensitive to changes in the variable concerned. The same is valid for $|\mathrm{B}-\mathrm{b}|,|\mathrm{C}-\mathrm{c}|$ and $|\mathrm{D}-\mathrm{d}|$. In our study, all of the differences (Table 2) were smaller than $\mathrm{s} \sqrt{2}=0.0065 \%$ (calculated from $\mathrm{s}=0.0046 \%$ ) and the method was demonstrated to be robust for all evaluated parameters.

The results for the other validation parameters (stability in solution, LOQ, intermediate precision, and accuracy) (Table 2) were also satisfactory. Therefore, the HPLC method was considered validated.

\section{Determination of organic impurities}

The content of organic impurities was calculated by peak area ratio according to equation 2 (Table 1 ) considering that $(i)$ it is not an assay calculation and does not rely on the use of CRMs of metronidazole and metronidazole impurity A, which are not available and therefore could not be used to guarantee metrological traceability; and (ii) the peak area of metronidazole and impurities are in the same order of magnitude, since the peak area of metronidazole 


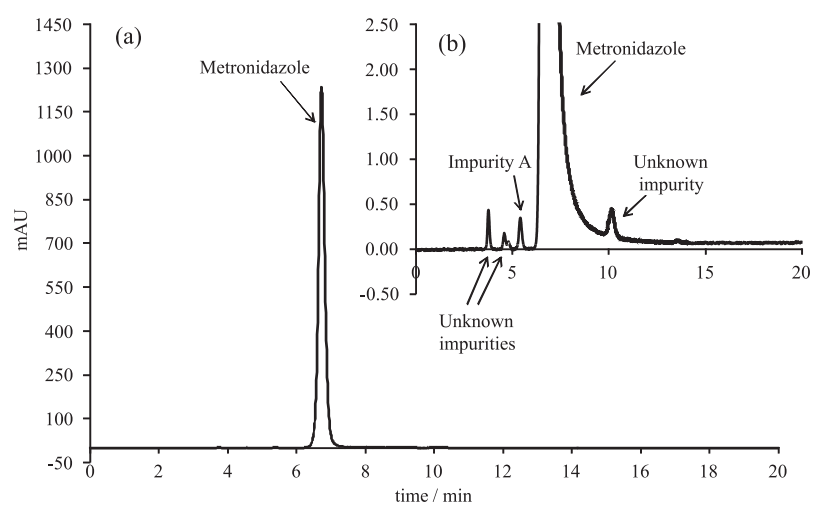

Figure 3. HPLC-DAD chromatogram for the related substances test of the metronidazole candidate CRM (500 $\left.\mu \mathrm{g} \mathrm{g}^{-1}\right)$ (a) and enlargement (b), showing the peaks of metronidazole $\left(t_{R}=6.7 \mathrm{~min}\right)$, metronidazole impurity A $\left(t_{R}=5.4 \mathrm{~min}\right)$ and unknown impurities $\left(t_{R}=3.7 \mathrm{~min}, 4.6 \mathrm{~min}\right.$ and $10.2 \mathrm{~min}$ ). Experimental conditions: HPLC reversed-phase column C18, $5 \mu \mathrm{m}, 25 \mathrm{~cm} \times 4.6 \mathrm{~mm}$ i.d.; pre-column C18, $5 \mu \mathrm{m}, 4.6 \mathrm{~mm}$ i.d; mobile phase, $1.36 \mathrm{~g} \mathrm{~L}^{-1}$ potassium dihydrogen phosphate-methanol (70:30, v/v);

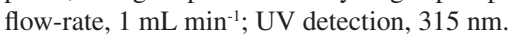

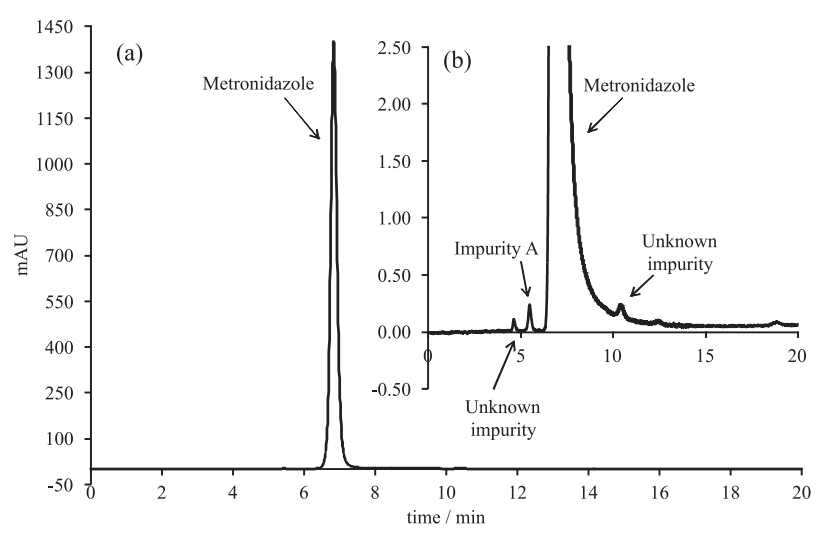

Figure 4. HPLC-DAD chromatogram for the related substances test of the metronidazole USP reference standard $\left(500 \mu \mathrm{g} \mathrm{g}^{-1}\right)$ (a) and enlargement (b), showing the peaks of metronidazole $\left(t_{R}=6.8 \mathrm{~min}\right)$, metronidazole impurity A $\left(t_{R}=5.4 \mathrm{~min}\right)$ and unknown impurities $\left(\mathrm{t}_{\mathrm{R}}=4.6 \mathrm{~min}\right.$ and $10.2 \mathrm{~min})$. Experimental conditions: same as in Figure 3.

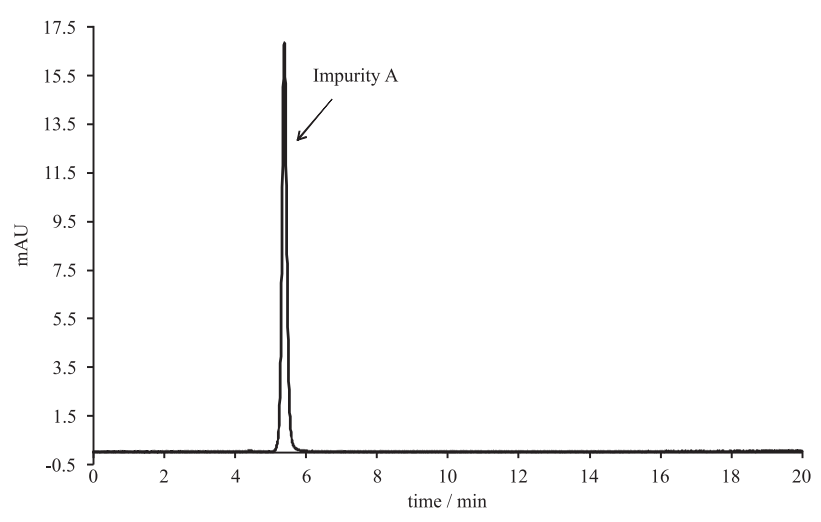

Figure 5. HPLC-DAD chromatogram for the related substances test of the metronidazole impurity A EP reference standard $\left(5 \mu \mathrm{g} \mathrm{g}^{-1}\right)$. Experimental conditions: same as in Figure 3. is obtained from the $5 \mu \mathrm{g} \mathrm{g}^{-1}$ solution and corrected by the dilution factor (DF).

Table 3 shows the related substances contents from three HPLC determinations, with calculations based on equation 2 (Table 1) and also on the assay against USP metronidazole reference standard (as standard for unknown impurities) and EP metronidazole impurity A reference standard. An agreement between the peak area ratio method and assay results was observed.

The average organic impurity content by peak area ratio was $0.0676 \%$, from which $0.02 \%$ corresponds to metronidazole impurity A and the other part to unknown impurities. These results are in accordance with the acceptance criteria of the European Pharmacopoeia V monograph $^{23}$ (maximum of $0.1 \%$ of each organic impurity and $0.2 \%$ of total organic impurities). The largest combined uncertainty $(0.0044 \%$, day 1$)$ was considered for $\mathrm{u}_{\mathrm{CRM}}$ calculation.

\section{Determination of inorganic and volatile impurities}

The content of inorganic impurities determined by residue on ignition was $0.0455 \%(\mathrm{n}=19)$, which is in accordance with the specified limit of $0.1 \%$ in the Brazilian Pharmacopeia IV monograph for metronidazole. ${ }^{22}$ The calculated value of $\mathrm{u}_{\text {inorg }}$ according to equation 4 (Table 1) was $0.0078 \%$ (considering $\mathrm{m}=503.76 \mathrm{mg}, \mathrm{U}=0.04 \mathrm{mg}$ and $\mathrm{k}=2$ ).

The volatiles content determined by loss on drying was $0.260 \%(n=16)$, which is also in accordance with the specified limit of $0.5 \%$ in the Brazilian Pharmacopeia IV monograph. ${ }^{22}$ The combined standard uncertainty $\left(\mathrm{u}_{\mathrm{vol}}\right)$ estimated by equation 4 (Table 1) was $0.013 \%$ $(\mathrm{m}=1010.45 \mathrm{mg}, \mathrm{U}=0.04 \mathrm{mg}$ and $\mathrm{k}=2)$. The water content determined by the Karl Fischer coulometric titration was $0.0245 \%(\mathrm{n}=10, \mathrm{u}=0.0004 \%)$, which was a smaller value compared to the result from the loss on drying test. This difference may be explained by the fact that the Karl Fischer method is insensitive to residual solvents; therefore, the Karl Fischer and loss on drying results may not be comparable. ${ }^{30}$

Homogeneity testing, short- and long-term stability studies

In the homogeneity testing, the single-factor analysis of variance of results for the 13 flasks analyzed in triplicate resulted in a mean square between groups $\left(\mathrm{MS}_{\text {between }}\right)$ of $2.7624 \times 10^{-5}$ and a mean square within groups $\left(\mathrm{MS}_{\text {within }}\right)$ of $2.1054 \times 10^{-6}$. Using equation 5 (Table 1), the uncertainty due to between-bottle (in)homogeneity $\left(\mathrm{u}_{\mathrm{bb}}\right)$ was estimated as $0.0029 \%$. 
Table 2. Validation results of HPLC-DAD method for determination of metronidazole related substances

\begin{tabular}{|c|c|c|c|c|c|}
\hline & Parameters & Substance & Results & Criteria & Conclusion \\
\hline Specificity & - & $\begin{array}{l}\text { Metronidazole and } \\
\text { impurity A }\end{array}$ & $\begin{array}{l}\mathrm{R}_{\mathrm{s}} \geq 3.5 \text {; peak purity } \\
\text { index }(\mathrm{PI}) \geq 0.9996 \text {; } \\
\text { no signal for diluent }\end{array}$ & $\begin{array}{l}\mathrm{R}_{\mathrm{s}} \geq 2.0 ; \mathrm{PI} \geq 0.98 \\
\text { no signal for diluent }\end{array}$ & Complies \\
\hline Stability in solution & $\begin{array}{c}\text { Regression analysis } \\
\text { of curve "analyte content } \\
\text { vs. time" }(80 \mathrm{~h})\end{array}$ & Metronidazole & $\mathrm{F}=3.28 ; \mathrm{F}_{\text {crit }}=4.38$ & $\begin{array}{c}\mathrm{F}<\mathrm{F}_{\text {crit }} \\
\text { (slope not significant) }\end{array}$ & Complies \\
\hline $\begin{array}{l}\text { Linearity and working } \\
\text { range }\end{array}$ & $\begin{array}{c}\text { Regression analysis } \\
\text { of curve "peak area } v s . \\
\text { concentration" }\end{array}$ & $\begin{array}{c}\text { Metronidazole } \\
\text { Impurity A }\end{array}$ & $\begin{array}{l}\mathrm{r}^{2} \geq 0.9996 \\
\mathrm{r}^{2}=1.0000\end{array}$ & $\mathrm{r}^{2}>0.98^{29}$ & Complies \\
\hline LOQ & - & $\begin{array}{c}\text { Metronidazole } \\
\text { Impurity A }\end{array}$ & $\begin{array}{l}0.0848 \mu \mathrm{g} \mathrm{g}^{-1} \\
0.0691 \mu \mathrm{g} \mathrm{g} \mathrm{g}^{-1}\end{array}$ & $\mathrm{LOQ}<0.5 \mu \mathrm{g} \mathrm{g}^{-1}$ & Complies \\
\hline Repeatability & $\begin{array}{l}\mathrm{CV} \text { of normalized } \\
\text { peak areas }\end{array}$ & Metronidazole & $\mathrm{CV}=0.48 \%$ & $\mathrm{CV} \leq 2.0 \%$ & Complies \\
\hline Intermediate precision & ANOVA & Metronidazole & $\mathrm{F}=0.46 ; \mathrm{F}_{\text {crit }}=4.96$ & $\mathrm{~F}<\mathrm{F}_{\text {crit }}$ & Complies \\
\hline Accuracy & Recoveries & Impurity A & $\begin{array}{l}100.57-102.60 \% \\
\quad \text { (no matrix); } \\
100.53-101.44 \% \\
\text { (with matrix) }\end{array}$ & $90-110 \%$ & Complies \\
\hline Robustness & $\begin{array}{l}\text { Analyte content under } \\
\text { different test conditions }\end{array}$ & Metronidazole & $\begin{array}{l}|\mathrm{A}-\mathrm{a}|=0.0022 \\
|\mathrm{~B}-\mathrm{b}|=0.0024 \\
|\mathrm{C}-\mathrm{c}|=0.0054 \\
|\mathrm{D}-\mathrm{d}|=0.0045\end{array}$ & $|X-x| \leq 0.0065$ & Complies \\
\hline
\end{tabular}

Table 3. Related substance content of metronidazole candidate CRM, determined by peak area ratio and by assay against USP and EP standards

\begin{tabular}{lccccc}
\hline \multirow{2}{*}{$\begin{array}{l}\text { Test } \\
\text { number }\end{array}$} & \multicolumn{2}{c}{ Peak area ratio (eq. 2) } & & \multicolumn{2}{c}{ Assay using USP and EP standards } \\
\cline { 2 - 3 } \cline { 5 - 6 } & Total related substances / $\%$ & Impurity A / $\%$ & & Total related substances / \% & Impurity A / \% \\
\hline 1 & 0.0692 & 0.0206 & 0.0696 & 0.0212 \\
3 & 0.0678 & 0.0204 & 0.0660 & 0.0195 \\
\hline Average & 0.0658 & 0.0200 & 0.0669 & 0.0193 \\
SD & 0.0676 & 0.0203 & 0.0675 & 0.0200 \\
CV / \% & 0.0014 & 0.0003 & 0.0015 & 0.0009 \\
\hline
\end{tabular}

The short-term stability studies were carried out to evaluate the CRM stability under transport conditions. ${ }^{17}$ The CRM flasks were exposed at the same time to the temperature of $50{ }^{\circ} \mathrm{C}$ and then analyzed individually on predetermined days. This design, which is called "classical", is performed under reproducibility conditions and therefore is expected to result in larger uncertainties compared to the "isochronous" design, performed under repeatability conditions (each flask is introduced into the oven on a pre-determined day and then all flasks are analyzed at the same time at the end of the study). However, the classical design was still considered more appropriate here, since the results are made available throughout the study.

The metronidazole contents during the 66 days of the short-term stability study are shown in Figure 6. The regression analysis of the curve resulted in an $\mathrm{F}$ value smaller than $\mathrm{F}_{\text {crit }}(3.23<3.92)$ and a p-value larger than $0.05(0.07)$; therefore, the curve slope was considered insignificant and the CRM stability under transport conditions $\left(50{ }^{\circ} \mathrm{C}\right.$, 66 days) was confirmed. Using equation 6 (Table 1 ), based on the value of $\mathrm{s}_{(\mathrm{b} 1)}=1.48 \times 10^{-5}$ (regression analysis) and on the 66-day period, the short-term stability uncertainty $\left(\mathrm{u}_{\mathrm{sts}}\right)$ was estimated as $0.0010 \%$. Since this value was smaller than the long-term stability uncertainty (see next paragraph), it was not considered relevant as an uncertainty component ${ }^{17}$ and was not included in the $\mathrm{u}_{\mathrm{CRM}}$ calculation.

The long-term stability studies were carried out to evaluate the stability of the metronidazole candidate CRM under storage conditions $\left(25^{\circ} \mathrm{C}\right)$. Figure 7 shows the metronidazole contents monitored throughout 42 weeks. 
The insignificant curve slope in the regression analysis, namely $\mathrm{F}<\mathrm{F}_{\text {crit }}(2.11<3.93)$ and p-value $>0.05(0.15)$, confirmed the CRM stability under storage conditions. The long-term stability uncertainty $\left(\mathrm{u}_{\mathrm{lts}}\right)$ was estimated as $0.0035 \%$ according to equation 6 (Table 1 ), considering $\mathrm{s}_{(\mathrm{b} 1)}$ as $2.24 \times 10^{-5}$ (regression analysis) and " $\mathrm{t}$ " as the storage shelf-life of 156 weeks ( 3 years).

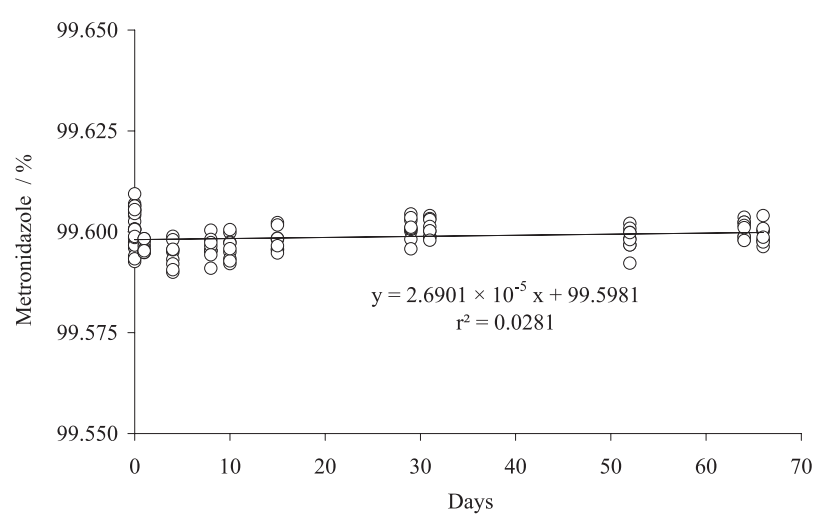

Figure 6. Results for the short-term stability study of metronidazole candidate CRM.

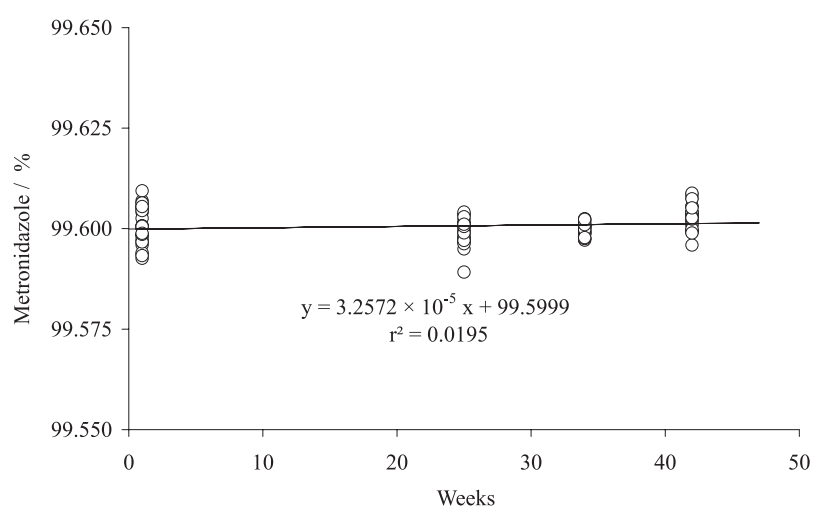

Figure 7. Results for the long-term stability study of metronidazole candidate CRM.

\section{CRM certified property value and uncertainty}

The certified value of the metronidazole CRM was determined by mass balance according to equation 1 (Table 1). Since metronidazole was dried prior to characterization and has to be dried by the consumer prior to use, as stated in the CRM certificate, the volatiles content was considered to be zero in the mass balance calculation and the uncertainty of volatiles content was disregarded in the CRM combined standard uncertainty calculation $\left(\mathrm{u}_{\mathrm{CRM}}\right)$. It should also be noted that the peak area ratio method for determination of organic impurities leads to small differences compared to the methods for quantification of inorganic and volatile impurities, since it deals only with organic compounds (analyte and impurities). However, since the volatiles were removed from the samples prior to characterization and the inorganic impurities content was very small, the mentioned differences were not considered to be significant.

As shown in Table 4, the certified property value calculated by mass balance was $99.887 \%$, the CRM combined standard uncertainty $\left(\mathrm{u}_{\mathrm{CRM}}\right)$ estimated by equation 7 (Table 1) was $0.007 \%$ and the CRM expanded uncertainty $\left(\mathrm{U}_{\mathrm{CRM}}\right)$ calculated according to equation 8 (Table 1), using a value of 2 as the coverage factor $k$ for a confidence level of approximately $95 \%,{ }^{31}$ was $0.015 \%$. The uncertainty $\mathrm{u}_{\mathrm{CRM}}$ due to uncertainties of input parameters $\mathrm{x}_{1} \ldots \mathrm{x}_{\mathrm{n}}$ was validated by a spreadsheet method described by Kragten, ${ }^{27}$ based on the separation of uncertainty sources.

Table 4. Metronidazole content of the certified reference material and uncertainties

\begin{tabular}{lccc}
\hline & Metronidazole $/ \%$ & $\mathrm{u}_{\mathrm{c}} / \%^{\mathrm{b}}$ & $\mathrm{U} / \%^{\mathrm{c}}$ \\
\hline Initial & 100.00 & - & - \\
Organic impurities & 0.0676 & 0.0044 & - \\
Inorganic impurities & 0.0455 & 0.0038 & - \\
Volatiles & $\mathrm{a}$ & $\mathrm{a}$ & - \\
Long-term stability & - & 0.0035 & - \\
Homogeneity & - & 0.0029 & - \\
$\begin{array}{l}\text { Certified property } \\
\text { value (mass balance) }\end{array}$ & 99.887 & 0.007 & 0.015 \\
\hline
\end{tabular}

${ }^{a}$ Volatiles were disregarded, since the CRM has to be dried prior to use. ${ }^{\mathrm{b}}$ Combined standard uncertainty. ${ }^{\mathrm{c}}$ Expanded uncertainty ( $95 \%$ confidence level, $\mathrm{k}=2$ ).

The certified value was cross-checked by differential scanning calorimetry (DSC), according to the recommendation for use of one primary method or two independent secondary methods for reference material certification. ${ }^{17} \mathrm{DSC}$ has been claimed as a "primary method", which refers to a method that does not rely on the use of "measurement standard for a quantity of the same kind". ${ }^{32}$ In practice, however, empirical corrections are needed, which "reduce the method's claim to produce traceable results" ${ }^{33}$ DSC is a "classical thermal analysis technique"18 based on the Van't Hoff law and its derived equation (equation 9, Table 1), which infers that the presence of impurities leads to a depreciation of the melting point. ${ }^{21}$ The DSC results for metronidazole $(99.82 \pm 0.01 \% \mathrm{~mol} / \mathrm{mol}$, previously dried sample) validated the mass balance result. The equivalence between the purity determined by DSC and the content determined by mass balance/HPLC had already been reported for highly pure substances. ${ }^{34,35}$

The CRM metronidazole content was also determined by titration in non-aqueous media with perchloric acid, 
according to the assay in the Brazilian Pharmacopeia IV monograph, ${ }^{22}$ and the results were in the range of $99.28 \%$ to $100.52 \%$. This large variability of titrimetric method results is not unusual. ${ }^{36}$ In addition, metronidazole is a 5-nitroimidazole compound, i.e., it contains a $\mathrm{NO}_{2}$ group on the $5^{\text {th }}$ position of the imidazole ring ${ }^{1,37}$ (Figure 1). All of the metronidazole impurities described in the literature ${ }^{38}$ also have the imidazole group, which is reported to react in a 1:1 molar ratio with perchloric acid ${ }^{39}$ therefore, they can react with the titrant. Due to the non-specificity of this technique ${ }^{33,40}$ and its large variability, the titration was less appropriate for certification purposes compared to the mass balance approach, even if its use would be recommended as a primary direct method. . $^{17,33,40}$

\section{Conclusions}

The Inmetro first batch of the candidate certified reference material of metronidazole, the first CRM of this active pharmaceutical ingredient, has been certified. The certified property value and the expanded uncertainty $(\mathrm{U})$, using the value of 2 as the coverage factor for a confidence level of approximately $95 \%$, was $(998.887 \pm 0.015) \mathrm{mg} \mathrm{g}^{-1}$ (previously dried sample).

The metronidazole CRM is an important tool for ensuring metrological traceability of measurement results to the SI by analytical laboratories and research institutes, in compliance with ISO/IEC 17025:2005.

\section{Acknowledgments}

The authors would like to thank Cristália Produtos Químicos e Farmacêuticos Ltda. and Medley S. A. Indústria Farmacêutica for their support.

\section{References}

1. Santana, C. M.; Ferrera, Z. S.; Padron, M. E. T.; Rodriguez, J. J. S.; Anal. Chim. Acta 2010, 665, 113.

2. Silva, M.; Schramm, S.; Kano, E.; Koono, E.; Porta, V.; Serra. C.; J. Chromatogr. Sci. 2009, 47, 781.

3. Tashtoush, B. M.; Jacobson, E. L.; Jacobson, M. K.; Drug Dev. Ind. Pharm. 2008, 34, 840.

4. Zip, C. M.; Dermatol. Clin. 2010, 28, 525.

5. Duewer, D. L.; Lippa, K. A.; Long, S. E.; Murphy, K. E.; Katherine, E. S.; Sniegoski, L. T.; Welch, M. J.; Tani, W.; Umemoto, M.; Anal. Bioanal. Chem. 2009, 395, 155.

6. ABNT NBR ISO/IEC 17025; Requisitos Gerais para Competência de Laboratórios de Ensaio e Calibração, ABNT: Rio de Janeiro, Brasil, 2005.

7. Koch, W. F.; Ma, B.; Accred. Qual. Assur. 2011, 16, 43.
8. United States Pharmacopeial Convention; http://www.usp.org accessed in March 2011.

9. Koch, W. F.; Pharm. Technol. 2010, 34, 118.

10. National Metrology Institute of Japan (NMIJ), List of Reference Materials; http://www.nmij.jp/english/service/C/crm/accessed in April 2011.

11. BIPM, JTCLM; Database of Higher-Order Reference Materials, Measurement Methods/Procedures and Services; http://www.bipm.org/jctlm accessed in April 2011.

12. Liu, J.; Yang, G.; Acta Metrol. Sin. 2010, 31, 135.

13. Yang, X.; Wang, L.; Wang, W.; Guo, H.; Acta Metrol. Sin. 2010, $31,88$.

14. Nogueira, R.; Rego, E. C. P.; Sousa, M. V. B.; Wollinger, W.; Silva, T. E.; Moreira, G. F.; Barin, J. S.; Laporta, L. V.; Mesko, M. F.; Bittencourt, C. F.; Rodrigues, J. M.; Cunha, V. S.; Braz. J. Pharm. Sci. 2011, 47, 339.

15. Nogueira, R.; Wollinger, W.; Silva, T. E.; Oliveira, L. M.; Rego, E. C. P.; Moreira, G. F.; Barin, J. S.; Laporta, L. V.; Mesko, M. F.; Bittencourt, C. F.; Rodrigues, J. M.; Cunha, V. S.; Braz. J. Pharm. Sci. 2011, 47, 351.

16. ISO Guide 34; General Requirements for the Competence of Reference Material Producers, ISO: Geneva, 2009.

17. ISO Guide 35; Reference Materials: General and Statistical Principles for Certification, ISO: Geneva, 2006.

18. Yip, Y.; Wong, S.; Choi, S.; Trends Anal. Chem. 2011, 30, 28.

19. Baldan, A.; Bosma, R.; Peruzzi, A.; van der Veen, A. M. H.; Shimizy, Y.; Int. J. Thermophys. 2009, 30, 325.

20. Hofer, J. D.; Olsen, B. A.; Richard, E. C.; J. Pharm. Biomed. Anal. 2007, 44, 906.

21. ASTM Standards E 928-08; Standard Test Method for Purity by Differential Scanning Calorimetry, ASTM International: Pennsylvania, 2008.

22. Farmacopeia Brasileira, $4^{\text {a }}$ ed., Atheneu: São Paulo, Brasil, 2002.

23. European Pharmacopoeia, $5^{\text {th }}$ ed., EDQM: Strasbourg, 2005.

24. International Conference on Harmonisation of Technical Requirements for Registration of Pharmaceuticals for Human Use (ICH); Validation of Analytical Procedures: Text and Methodology Q2(R1), ICH: London, 2005.

25. Bedregal, P.; Torres, B.; Ubillús, M.; Mendoza, P.; Montoya, E.; J. Radioanal. Nucl. Chem. 2008, 278, 801.

26. Eurachem/Citac Guide CG 4; Quantifying Uncertainty in Analytical Measurement, $2^{\text {nd }}$ ed., London, 2000.

27. Kragten, J.; Analyst 1994, 119, 2161.

28. The United States Pharmacopeia 32, National Formulary 27; The United States Pharmacopeial Convention: Rockville, 2009.

29. Ribani, M.; Bottoli, C. B. G.; Collins, C. H.; Jardim, C. S. F.; Melo, L. F. C.; Quim. Nova 2004, 27, 771.

30. Smith, R. J.; Webb, M. L.; Analysis of Drug Impurities, Blackwell Publishing: Oxford, 2007.

31. ABNT/Inmetro, Guia para a Expressão da Incerteza de Medição, 3a. ed., ABNT: Rio de Janeiro, Brasil, 2003. 
32. Joint Committee for Guides in Metrology (JCGM); International Vocabulary of Metrology: Basic and General Concepts and Associated Terms (VIM), $3^{\text {rd }}$ ed, BIPM: Sèvres, France, 2008.

33. Duewer, D. L.; Parris, R. M.; White, E. V.; May, W. E.; Elbaum, H.; An Approach to the Metrologically Sound Traceable Assessment of the Chemical Purity of Organic Reference Materials, National Institute of Standards and Technology (NIST): Gaithersburg, 2004.

34. Moreira, G. F.; Balbo, A.; Achete, C.A.; Barin, J. S.; Wollinger, W.; Nogueira, R.; Bittencourt, C. F.; Rodrigues, J. M.; Produto \& Produção 2010, 11, 22. http://seer.ufrgs.br/ProdutoProducao/ article/view/11821/7057 accessed in December 2011.

35. Mathkar, S.; Kumar, S.; Bystol, A.; Olawoore, K.; Min, D.; Marcovich, R.; Rustum, A. J.; Pharm. Biomed. Anal. 2009, 49, 627.
36. Rodomonte, A. L.; Montinaro, A.; Bartolomei, M.; J. Pharm. Biom. Anal. 2006, 42, 56.

37. Cronly, M.; Behan, P.; Foley, B.; Malone, E.; Regan, L.; J. Chromatogr., B: Anal. Technol. Biomed. Life Sci. 2009, 877, 1494.

38. LGC Standards; Pharmaceutical Reference Substances and Impurities for LGC GmbH, LGC: Teddington, 2011.

39. Greenhow, E. J.; Spencer; L. E.; Analyst 1973, 98, 81.

40. Gorog, S.; J. Pharm. Biomed. Anal. 2005, 36, 931.

Submitted: May 23, 2011

Published online: January 10, 2012 